\title{
Editorial
}

Dogan Yucel

\section{Turkish journal of biochemistry is an open access journal again}

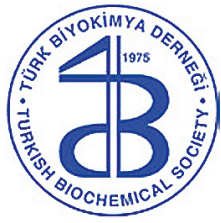

\section{Türk Biyokimya Dergisi Yeniden Açik Erişimli Bir Dergi}

https://doi.org/10.1515/tib-2021-0044

Received February 27, 2021; accepted March 1, 2021

After five years, as of January 2021, the Turkish Journal of Biochemistry (TJB) has become an open Access journal again. TJB has been listed in SCI-E since 2007 and published under the De Gruyter since 2015. De Gruyter - TJB collaboration will continue in the new period. Our primary goal is to improve the journal's quality more and more and increase the impact factor of TJB.

During the COVID-19 pandemic, laboratory medicine's importance has become more apparent, and essentially we gave priority to articles related to COVID-19 and published COVID-19 papers in almost every issue of 2020. There have been quests on the use of biomarkers for diagnosis, prognosis and treatment in patients with COVID-19, these quests are continuing. We try to publish those studies having novelty related to COVID-19.

On the other hand, laboratory hematology has an increasing role for about 10 years due to technological advancements. In addition to first-line tests, namely complete blood count, new blood cell population parameters have been introduced to the clinical laboratories, such as nucleated red blood cell count, reticulocyte fractions, mean reticulocyte hemoglobin content, immature granulocytes count, and immature platelet (IPF) count [1]. Automated blood smear preparation and morphological analysis of peripheral smear by deep learning or artificial intelligence techniques have been a groundbreaking development in laboratory hematology. Also, the results of these procedures can be reported with diagnostic algorithms in a completely automated way [2,3].

Dogan Yucel, Department of Medical Biochemistry, Faculty of Medicine, Lokman Hekim University, Ankara, Turkey,

E-mail: dogan.yucel@lokmanhekim.edu.tr
This issue contains 15 papers; three of them consists of two review article and a case report, the remainings are research articles. The first review article by Mackness and Sozmen is on the paraoxonase- 1 enzyme (PON1). PON1 is a frequently studied enzyme in heart disease, diabetes, neurological diseases and cancer, in particular. In PubMed, there are 775 clinical studies, randomized controlled trials and clinical trials with the search term "paraoxonase + arylesterase" between 1982 and 2020 [4]. In this critical review, some truths and misconceptions that frequently encountered in the literature are highlighted. Platelet-rich plasma (PRP) is increasingly used in clinical practice. In the second review article the use of PRP as a radioprotector in radiotherapy is discussed [5]. The case report is on the first observation of hemoglobin G-Norfolk in the Turkish population [6].

Three of the other papers are on the relatively newly developed blood count parameters. In the article of Bal et al. [7], the efficiency of lymphocyte to C-reactive protein ratio (LCR) to evaluate the severity of the SARS-CoV-2 infection in mild/moderate, severe and critically ill patients is reported, and the authors conclude that LCR is superior to the neutrophil-to-lymphocyte ratio in this regard. In another article, Duzenli and Altinkaynak report "reticulocyte hemoglobin equivalent" in the differential diagnosis of iron deficiency anemia and $\beta$-thalassemia trait in children [8]. They propose two cut-off values for reticulocyte hemoglobin to discriminate iron deficiency anemia and $\beta$-thalassemia trait in children. Buyuekeren et al. [9] investigate the efficiency of immature granulocyte count and delta neutrophil index in determining the etiology of neonatal sepsis.

There are papers on instrument evaluation; one on a verification study of a modern automated hemocytometer Sysmex XN-3100 [10], and another one on a method comparison study of four different HPLC devices used for hemoglobinopathy screening (Agilent 1100, Bio-Rad 
Variant II, TOSOH G8 and Trinity Biotech Ultra 2) [11]. In another method comparison study, an erythrocyte sedimentation rate (ESR) analyzer, Vision C, is evaluated against the modified Westergren method [12].

Preanalytical phase is the most important stage for laboratory errors in laboratory medicine. This reality is particularly important for hemostasis assays. In this issue, there are two articles on the preanalytical phase of hemostasis assays. One of them is an abridged guideline prepared by the Working Group on Preanalytical Phase of Turkish Biochemical Society also posted on the EFLM website [13]. The other article by Ongen and Sitar is on the effects of transportation and freeze-thaw procedure in plasma samples obtained from 104 patients on hemostatic assays [14].

The rest of the articles are clinical investigations on miscellaneous topics such as miR-144-3p expression in cases with increased and normal hemoglobin $\mathrm{F}$ in homozygous sickle cell anemia, diurnal variation of ESR, drug resistance in multiple myeloma, and the relationship between 25-OH-vitamin D deficiency and iron-deficiency anemia in the pediatric population [15-18].

I hope the readers enjoy the issue and use it in their scientific studies.

I would like to dedicate the first issue of the 2021 year to the healthcare workers who died from the pandemic worldwide.

\section{References}

1. Kratz A, Brugnara C. Automated hematology analyzers: state of the art. Clin Lab Med 2015;35:225-35.

2. Buoro S, Lippi G. Harmonization of laboratory hematology: a long and winding journey. Clin Chem Lab Med 2018;56:1578-85.

3. Lippi G, Plebani M. Recent developments and innovations in red blood cells diagnostics. J Lab Precis Med 2018. https://doi.org/10. 21037/jlpm.2018.07.09.

4. Sozmen E, Mackness M. A critical review on human serum paraoxonase 1 in the literatüre: truths and misconceptions. Turk J Biochem 2021;46.
5. Cihan YB, Baykan H. The effect of platelet rich plasma on radiotherapy. Turk J Biochem 2021;46. https://doi.org/10.1515/ tjb-2020-0072.

6. Unal H, Atay A, Yucel M, Narin F, Ceylaner S, Canatan D. First observation of hemoglobin G-Norfolk in Turkish population. Turk J Biochem 2021;46. https://doi.org/10.1515/tjb-2019-0476.

7. Bal T, Dogan S, Cabalak M, Dirican E. Lymphocyte-to-C-reactive protein ratio may serve as an effective biomarker to determine COVID-19 disease severity. Turk J Biochem 2021;46. https://doi. org/10.1515/tjb-2020-0410.

8. Kar YD, Altinkaynak K. Reticulocyte hemoglobin equivalent in differential diagnosis of iron deficiency, iron deficiency anemia and $\beta$-thalassemia trait in children. Turk J Biochem 2021;46.

9. Büyükeren M, Celik HT, Yigit S, Portakal O, Sancak B, Yurdakok M. The role of the delta neutrophil index in determining the etiology of neonatal sepsis. Turk J Biochem 2021;46. https://doi.org/10. 1515/tjb-2020-0030.

10. Incir S, Palaoglu KE. Evaluation of the performance of Sysmex XN-3100 automated hematology analyzer regarding the Sysmex XE-2100 and microscopic examination. Turk J Biochem 2021;46. https://doi.org/10.1515/tjb-2020-0004.

11. Ercan M, Akbulut D, Avcı E, Oguz EF, Kader S, Abusoglu G. Evaluation of four different HPLC devices for hemoglobinopathy screening. Turk J Biochem 2021;46.

12. Erdogan S, Firat R, Avcoglu G, Yilmaz G, Erel O. Is Vision C interchangeable with the modified Westergren method fort he erythrocyte sedimentation rate? Turk J Biochem 2021;46.

13. Senes M, Inal B, Aksungar B, Cinaroglu I, Eker P, Sonmez C, et al. TBS preanalytical phase working Group Survey studyprenalytical phase in coagulation laboratories. Turk J Biochem 2021;46. https://doi.org/10.1515/tjb-2019-0512.

14. Ongen BI, Sitar ME. Effect of transportation and freeze-thaw procedure on hemostatic tests. Turk J Biochem 2021;46.

15. Guzelgul F, Seydel GS, Alparslan N, Aksoy K. Investigation of miR-144-3p expression levels in HbSS cases with high and normal Hb F. Turk J Biochem 2021;46. https://doi.org/10.1515/tjb-20190496.

16. Yucel M, Ihtiyar A, Koseoglu M. The effect of diurnal variation on erythrocyte sedimentation rate. Turk J Biochem 2021;46. https:// doi.org/10.1515/tjb-2020-0025.

17. Oksuzoglu E, Kozalak G. Inhibition of apoptosis may lead to the development of bortezomib resistance in multiple myeloma cancer cells. Turk J Biochem 2021;46.

18. Gul H, Bozkurt HB, Ozpolat G, Celik S. A data analysis study: is there a relationship between $25(\mathrm{OH}) \mathrm{D}$ deficiency and irondeficient anaemia in the pediatric population. Turk J Biochem 2021;46. https://doi.org/10.1515/tjb-2020-0355. 